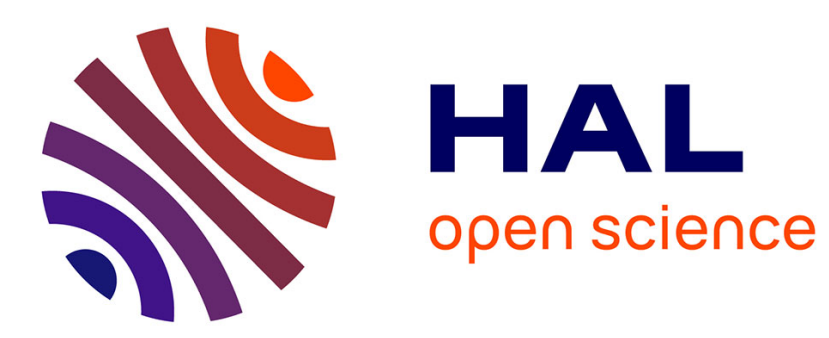

\title{
D.C. CONDUCTIVITY OF ANTARCTIC ICE IN RELATION TO ITS CHEMISTRY
}

Michel Legrand, J.-R. Petit, Y. Korotkevich

\section{To cite this version:}

Michel Legrand, J.-R. Petit, Y. Korotkevich. D.C. CONDUCTIVITY OF ANTARCTIC ICE IN RELATION TO ITS CHEMISTRY. Journal de Physique Colloques, 1987, 48 (C1), pp.C1-605-C1611. 10.1051/jphyscol:1987183 . jpa-00226448

\section{HAL Id: jpa-00226448 https://hal.science/jpa-00226448}

Submitted on 1 Jan 1987

HAL is a multi-disciplinary open access archive for the deposit and dissemination of scientific research documents, whether they are published or not. The documents may come from teaching and research institutions in France or abroad, or from public or private research centers.
L'archive ouverte pluridisciplinaire HAL, est destinée au dépôt et à la diffusion de documents scientifiques de niveau recherche, publiés ou non, émanant des établissements d'enseignement et de recherche français ou étrangers, des laboratoires publics ou privés. 


\title{
D.C. CONDUCTIVITY OF ANTARCTIC ICE IN RELATION TO ITS CHEMISTRY
}

\author{
M. LEGRAND, J. $+R$. PETIT and Y.S. KOROTKEVICH* \\ Laboratoire de Glaciologie et Géophysique de I'Environnement, \\ B.P. 96, F-38402 st-Martin-d'Hêres Cedex, France \\ "The Arctic and Antarctic Research Institute, Fontanka 34, \\ 191104 Leningrad, USSR
}

\begin{abstract}
RESUME
La conductivite electrique de la glace naturelle varie en géneral avec l'acidité de l'eau de fusion. Cette méthode a eté utilisée avec succès par. Hammer (1) pour détecter les empreintes d'eruptions volcaniques dans la glace du Groèn land.

Dans ce papier plusieurs profils de conductivité sont présentés pour deux sites antarctiques (Vostok et Pole Sud) en liaison avec une étude globale des impuretes solubles. Nos profils mettent en evidence un important "double pic" de conductivite et d'acide sulfurique dans la neige déposée durant les "annés Tambora (1815)", ce qui nous sert d'horizon repere.

Parmi les trois acides habituellement présents dans la glace $\left(\mathrm{H}_{2} \mathrm{SO}_{4}, \mathrm{HCl}\right.$ et $\mathrm{HNO}_{3}$ ) $\mathrm{HCl}$ et $\mathrm{HNO}_{3}$ semblent jouer un rôle prépondérant sur les niveáux de conductivité. Par ailleurs un effet négatif des aluminosilicates est mis en évidence. Ces résultats suggèrent que des impuretés dans la glace seraient localisés aux joints de grains où le $\mathrm{pH}$ pourrait atteindre de tres basses valeurs. Cette hypothese est en accord avec le modele de conduction anterieurement propose par Wolff et Paren (2).
\end{abstract}

\section{ABSTRACT}

The D.C. conductivity of natural ice generaliy shows a strong correlation with the acidity of the meltwater sample. This method was successfully applied by Hammer (1) to detect debris of volcanic eruptions recorded in Greenland ice cores.

In this paper we study several conductivity profiles for antarctic ice cores (Vostok and South Pole stations) in relation with a comprehensive study of soluble species. Our profiles revealed an important "double spike" on both conductivity and sulfuric acid record for snow deposited during the "Tambora years (1815)" which is used as a statigraphic marker.

Among the three acids $\left(\mathrm{H}_{2} \mathrm{SO}_{4}, \mathrm{HCl}\right.$ and $\left.\mathrm{HNO}_{3}\right)$ usually present in the ice $\mathrm{HCl}$ and $\mathrm{HNO}_{3}$ seem to be more effective than $\mathrm{H}_{2} \mathrm{SO}_{4}$ on the conductivity background. In addition it is suggested a negative effect of aluminosilicates. These results suggest that impurities are located at grain boundaries where the $\mathrm{pH} c$ an reach very low values. This assumption is in agreement with the conductivity model previously proposed by Wolff and Paren (2).

\section{INTRODUCTION}

Deep ice cores in Green land and Antarctic ice sheets provide continuous records of climate and atmospheric content over periods as long as 100 kyears or more. Many features of past environments may be reconstructed, including their historical volcanism. In relation to this topic, Hammer (1) has shown that electrical conductivity measurements (E.C.M.) on Greenland ice core samples are essentially dependent on the acidity of the meltwater, and he proposes a volcanism reconstruction covering the last 10,000 years. 
Similar studies have been performed on Antarctic ice (Maccagnan et al ( 3 ), Maccagnan and Duval (4), Schwander (5)). However their results deal with certain phenomenological and physical aspects of the DC conductivity and no calibration curve was established for this ice, often different from Greenland ice with respect to impurity content.

Zanolini (6) has examined twe lve conductivity spikes observed on a continuous E.C.M. profile from a $200 \mathrm{~m}$ deep ice core at D 57 (Terre Adelie) in a more comprehensive chemical study $\left(\mathrm{H}^{+}, \mathrm{NO}_{3}\right.$, and $\mathrm{SO}_{4}^{-}$measurements). Ten peaks were found to be positively correlated with increases of $\mathrm{HNO}_{3}$ or $\mathrm{H}_{2} \mathrm{SO}_{4}$ and two had no correlation. For similar increases in $\mathrm{H}^{+}$content, this ${ }^{3}$.C.M. ${ }^{2}$ record suggests that $\mathrm{HNO}_{3}$ may be more related to conductivity than $\mathrm{H}_{2} \mathrm{SO}_{4}$. If true, the interpretation of conductivity profiles in term of volcanism becomes questionable if not checked by chemical analysis, since $\mathrm{HNO}_{3}$ is not as sumed to be of volcanic origin. The two "ghost peaks", unexplained by chemical analysis, cast doubt on the results obtained for D 57 since the E.C.M. signal is temperature dependent and the core temperature was not monitered during E.C.M. measurements.

In addition to the search for optimal conditions to obtain reliable E.C.M. profiles, the objective of this study is to quantify the influence of each acid ( $\mathrm{H}_{2} \mathrm{SO}_{4}, \mathrm{HNO}_{3}$ and $\mathrm{HCl}$ ) on the $\mathrm{DC}$ conductivity using a comprehensive study of soluble species present in Antarctic ice.

\section{EXPERIMENTAL STRATEGY AND METHODS}

E.C.M. was performed using a pair of sharp electrodes ( $10 \mathrm{~mm}$ apart) pushed a few millimetres into the core and moved by a sledge over a plane surface cut paralle1 to the core axis. The applied voltage was $1000 \mathrm{~V}$ and the temperature of the sample (around $-15^{\circ}$. C) was carefully monitered. A $10 \mathrm{~mm}$ thick of outer layer of the core was first removed in order to avoid possible ageing effects on stored cores.

We carried out two series of measurements on ice cores drilled at two Antarctic stations : South Pole $\left(90^{\circ} \mathrm{S}, 2800 \mathrm{~m}\right.$ elevation a.s.1) and Vostok $\left(78^{\circ} \mathrm{S}, 107^{\circ} \mathrm{E}\right.$, $3600 \mathrm{~m} \mathrm{a.s.1).} \mathrm{First,} \mathrm{we} \mathrm{selected} \mathrm{ice} \mathrm{samples} \mathrm{corresponding} \mathrm{in} \mathrm{time} \mathrm{to} \mathrm{the} \mathrm{huge}$ eruption of Tambora in 1815 which was followed by a large input of $\mathrm{H}_{2} \mathrm{SO}_{4}$. This event can be easily identified on a continuous record (Fig. 1) since it is preceded by another eruption, seven years earlier of an unknown volcano (no historical record) (Legrand and Delmas (7)). This "twin" peak was identified at South Pole in seven cores drilled in a $10 \mathrm{~km}$ radius around the station, and in 3 different cores at vostok. The depth of the Tambora event is consistent with the accunulation rate deduced from total Beta radioactivity measurements at each location. The Tambora

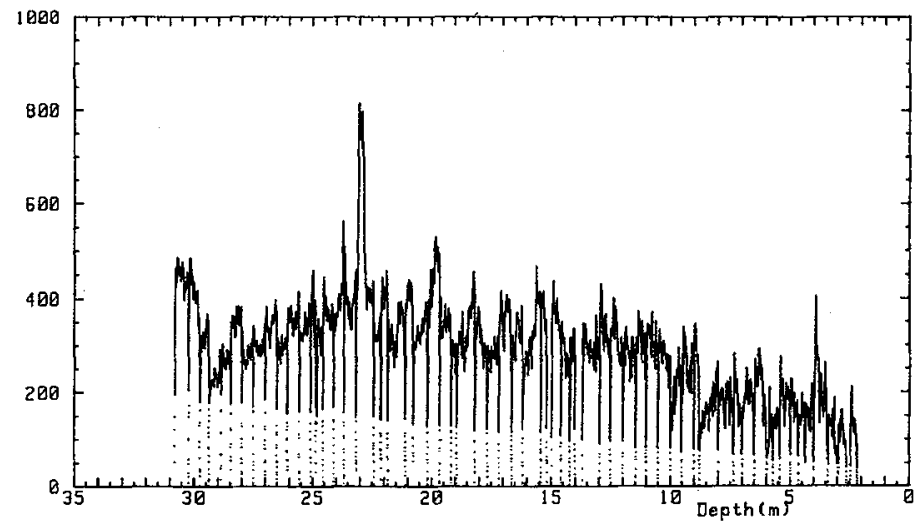

Fig. 1 : Continuous E.C.M. profile obtained at South Pole Station. The highest peak, at $23 \mathrm{~m}$ depth, corresponds to the Tambora eruption, preceded by another volcanic eruption. A peak at $4 \mathrm{~m}$ depth corresponds to the Mt Agung eruption in 1963 (not studied in this paper). 
layer is found at a depth of $23 \mathrm{~m}$ at South Pole and $15 \mathrm{~m}$ at Vostok. This double spike is also seen on other profiles covering this time period performed at various locations (at Dome C, Legrand (8); at Siple, Schwander (5) and at D 57 Zanolini (6)). These two peaks, seven years apart and the largest of the two last centuries recorded anywhere in Antarctica, are a valuable aid in the dating of snow layers. For example, these two volcanic reference layers were used by Zanolini et al. (9) to establish the chronology of a $200 \mathrm{~m}$ deep ice core from $D 57$ where dating is very difficult in relation to an irregular accumulation variation and glaciological parameters (ice flow).

From Fig. 1, the E.C.M. signal tends to increase with depth from the surface down to $30 \mathrm{~m}$, attribuable to the increased contact beetwen firn and electrodes due to firn hardening as we 11 as the increase in the conductivity of firn as its density increases. In order to calibrate the Vostok E.C.M. signal to a depth of about $25 \mathrm{~m}$ we applied a correction factor of 1.4 to these data, representing approximatively the ratio between 23 and $15 \mathrm{~m}$ signals on Fig. 1 .

The second set of measurements was made on samples from the 2083 m Vostok core, retrograded in Grenoble. These samples cover the last $150 \mathrm{kyrs}$ and have been used in stable isotope studies to reconstruct the last climatic cycle (Lorius et al. (10)). Note that during glacial climate, the ice shows a drastic enhancement of insoluble and soluble compounds (Legrand et al., to be published).

The E.C.M. signal is temperature dependent. Fig. 2 represents the signal from the core before and during the Tambora spike versus the reciprocal of temperature.

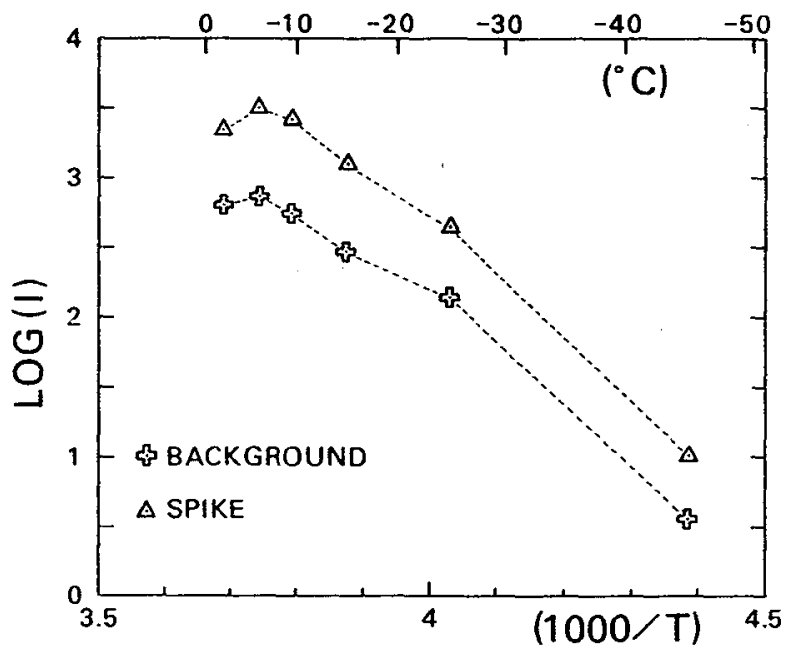

Assuming that current (i) is a function of temperature (T) according to an Arrhenius law ( $\left.i=i_{0} \quad \exp -E / R T\right)$, an activation energy of $0.25 \mathrm{eV}$ is found in the -25 to $-9^{\circ} \mathrm{C}$ temperature range. For temperatures higher than - $6^{\circ} \mathrm{C}$ the signal decreases. This may be due to weaker contact between the electrodes and the ice crystals since the firn becomes too soft for good contact. Another possibility is a drastic modification of the conduction process.In the -25 to $-9^{\circ} \mathrm{C}$ temperature range, our activation energy is consistent with previous studies (Hammer (11), Neftel et al.(12), Reynolds and Paren (13)) and we use this value in normalizing all data to a temperature of $-15^{\circ} \mathrm{C}$.

Fig. 2 : The conductivity signal as a function of temperature : triangles refer to the Tambora signal and crosses to an undisturbed level (sample from South Pole Station).

We have measured major ions (i.e. $\mathrm{Na}^{+}, \mathrm{NH}_{4}^{+}, \mathrm{K}^{+}, \mathrm{Ca}^{++}, \mathrm{Mg}^{++}, \mathrm{H}^{+}, \mathrm{Cl}^{-}, \mathrm{NO}_{3}^{-}$and $\mathrm{SO}_{4}^{--}$) on the corresponding samples. $\mathrm{H}^{+}$content was measured by an acid Eitration method which rules-out the influence of $\mathrm{Co}_{2}$ (Legrand et al. (14)). All other ions were determined by ion chromatography using stringent contamination free techniques (Legrand et al. (15)). As already discussed, (see, for example, Legrand and Delmas (16)), such a comprehensive study can be used to identify the origin of each ion. In this way, we have demonstrated that the proton present in ice comes from HNo $\mathrm{H}_{2} \mathrm{SO}_{4}$ and sometimes HCI (calculations of each contribution are detailed in this volume; see Legrand (17)). 


\section{THE INFLUENCE OF THE PROTON ORIGIN}

Fig. 3 shows the E.C.M. record of the Tambora eruption for Vostok and South Pole ice cores with resulfs for each origin of acidity. The HCl concentration is very low $\left(\chi 0.2 \mu \mathrm{Eq} .1^{-1}\right.$ ) and is assumed to have a behaviour similar to that of HNO . $^{\circ}$ The sum of $\mathrm{HCl}+\mathrm{HNO}_{3}$ is therefore reported. The E.C.M. signal (i) is plotted versus total acidity $\left(\left[\mathrm{H}^{+}\right]\right)^{3}$ in Fig. 4 .

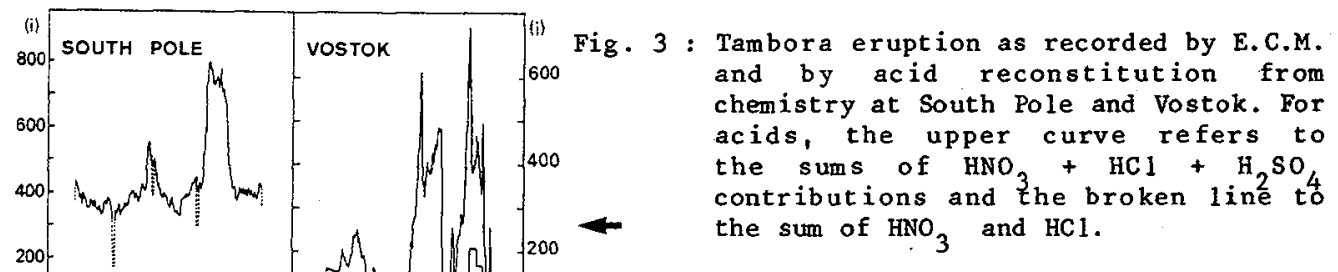

Fig. 4 : Total acidity $\mathrm{H}^{+}$as a function of
E.C.M. signal for South Pole
(stars) and Vostok (triangles) data
from Fig. 3.

Fig. 4 : Total acidity $\mathrm{H}^{+}$as a function of
E.C.M. signal for South Pole
(stars) and Vostok (triangles) data
from Fig. 3.

Fig. 4 : Total acidity $\mathrm{H}^{+}$as a function of
E.C.M. signal for South Pole
(stars) and Vostok (triangles) data
from Fig. 3.

Fig. 4 : Total acidity $\mathrm{H}^{+}$as a function of
E.C.M. signal for South Pole
(stars) and Vostok (triangles) data
from Fig. 3.

Tambora eruption as recorded by E.C.M. and by acid reconstitution from chemistry at South Pole and Vostok. For the sums of HNO $+\mathrm{HCl}+\mathrm{H}_{2} \mathrm{SO}_{4}$ contributions and the broken line to the sum of $\mathrm{HNO}_{3}$ and $\mathrm{HCl}$.
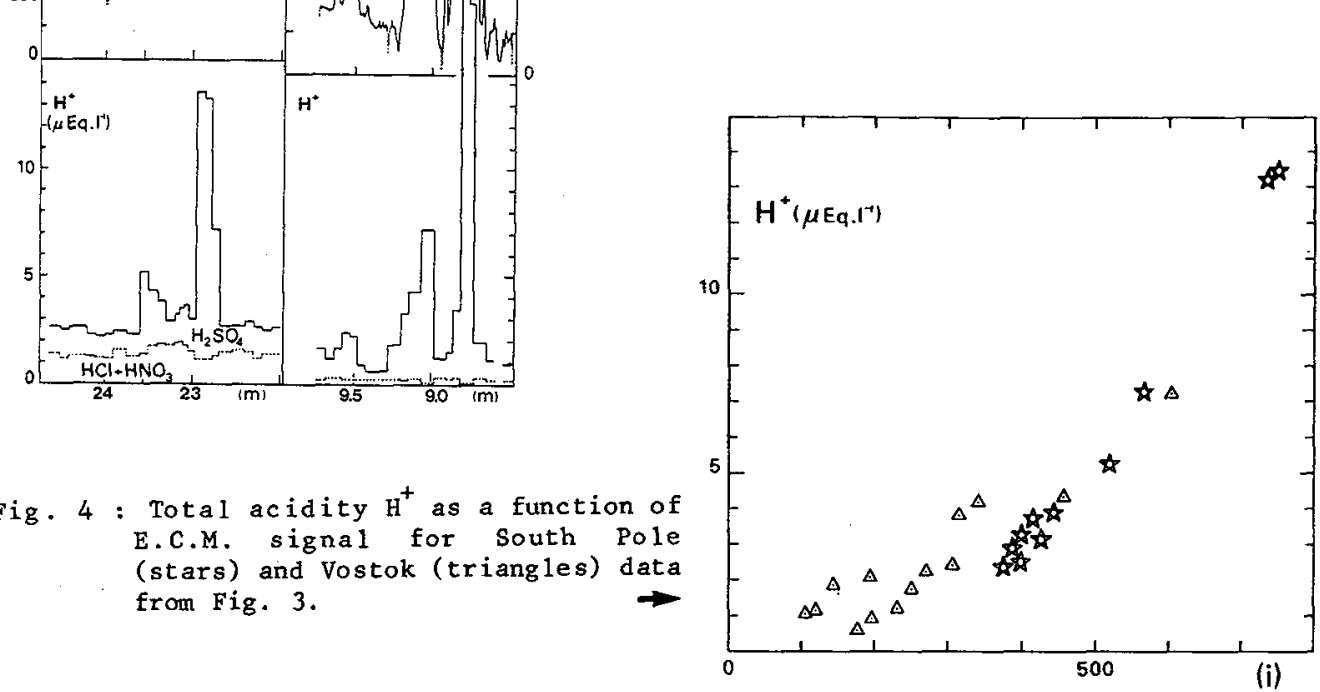

Data are fitted by a regression function $i^{\alpha}=a\left[H^{\dagger}\right]$, where $\alpha$ and a are estimated by the least squares method. The values foi a and $\alpha$ are $1.110^{-6}$ (relative units) and 2.48 for South Pole data and $9.510^{-4}$ and 1.58 for Vostok respectively. For low acidity, around $2 \mu \mathrm{Eq} . \mathrm{l}^{-1}$ the conductivity signal appears significantly higher at South Pole than at Vostok.

The chemical analysis shows that $\mathrm{H}_{2} \mathrm{SO}_{4}$ represents the predominant contribution of the acidity background for Vostok $\left(1.1 \mu \mathrm{kq} .1^{-1}\right.$ or $\left.81 \%\right)$, HNO being minor $(0.26$ $\mu \mathrm{Eq} \cdot 1^{-1}$ or $19 \%$ ) and HC1 not present at all. On the contrary for South Pole, only $45 \%$ of the acidity is due to the presence of $\mathrm{H}_{2} \mathrm{SO}_{4}\left(1 \mu \mathrm{Eq} .1^{1}\right)$ and $55 \%$ is due to $\mathrm{HNO}_{3}$ and $\mathrm{HC} 1\left(1.5 \mu \mathrm{Eq} .1^{-1}\right)$. In order to estimate the specific effect of other components, $\left[\mathrm{HNO}_{3}+\mathrm{HCl}\right]$ on one hand, $\left[\mathrm{H}_{2} \mathrm{SO}_{4}\right]$ on the other, we assume that the E.C.M. signal is a function of an effective acidity ( $H_{\text {f }}$ ) according to the equation: $i^{\alpha}=a\left(H_{1}\right)$, where this effective acidity is a finear combination of
three main components ${ }^{\prime}$

$$
\mathrm{H}_{\mathrm{eff}}=\left[\mathrm{HNO}_{3}+\mathrm{HCl}\right]+\mathrm{b}\left[\mathrm{H}_{2} \mathrm{SO}_{4}\right]
$$

eq: 1

$\mathrm{HCl}$ and $\mathrm{HNO}_{3}$ are assumed to have a similar behavior with respect to $\mathrm{H}_{\text {ff }}$. The best fit of the 30 data points in Fig. 3 gives 1.8 for $\alpha, 3.98$ for a and 0.95 for $b$. The regression coefficient is 0.98 . We tested the sensitivity of the result to $\alpha$ and $b$ in two ases : i) when we remove the highest 3 values (where $H^{+}$is greater than 7 $\mathrm{pEq} .1^{-1}$ ) and $\mathrm{ii}$ ) when the calibration coefficient used to compensate for the 
varying densification effect between the two locations is reduced to 1.2 . In both cases, $\alpha$ and $b$ decrease toward 1.3 and 0.4 respectively, representing extreme values.

These data suggest that the influence of $\mathrm{HNO}_{3}$ and $\mathrm{HCl}$ on the conductivity background is more important than $\mathrm{H}_{2} \mathrm{SO}_{4}$. This can be explained considering the model proposed by Wolff and Paren (2). Indeed $\mathrm{HCl}, \mathrm{HNO}_{3}$ and $\mathrm{H}_{2} \mathrm{SO}_{4}$ (at least for the first dissociation) are strong acids, but the second dissociation of $\mathrm{H}_{2} \mathrm{SO}_{4}$ is an equilibrium reaction which depends on the $\mathrm{pH}$ :

$$
\mathrm{HSO}_{4}^{-}+\mathrm{H}_{2} \mathrm{O}=\mathrm{SO}_{4}^{--}+\mathrm{H}_{3} \mathrm{O}^{+} \quad \text { with } \mathrm{K}=\frac{\left[\mathrm{SO}_{4}^{-}\right]\left[\mathrm{H}_{3} \mathrm{O}^{+}\right]}{\left[\mathrm{HSO}_{4}\right]}=10^{-1.9}
$$

For several reasons already developed (Legrand, 17) we agree with the idea (previous ly proposed by Maccagnan (18), Wolff and Paren (2)) that sulfuric acid is mainly in the ice at the grain boundaries. In this case, the pH of the liquid vain can reach low values ( $i . e . \mathrm{pH}=2.5$ when $\mathrm{b}=0.7$ and $\mathrm{pH}=1$ when $\mathrm{b}=0.4$ ).

A value of 0.4 for b would suggest that a small fraction of $\mathrm{HCl}$ or mNo is located at grain boundaries. This assumption is not overly surprising. Indeed, for the opposite case of $\mathrm{H}_{2} \mathrm{SO}_{4}$, Legrand (17) concludes that only a small fraction of $\mathrm{HNO}_{3}$ is deposited directly at the snow surface. So the incorporation into the ice would be better for $\mathrm{HNO}_{3}$ than $\mathrm{H}_{2} \mathrm{SO}_{4}$ (at least during the deposition step). This conclusion needs to be checked by other experiments on natural ice and doped laboratory-grown crystals.

It is also important to note that our present results do not question the calibration curve established by Hammer on Greenland ice cores (1). Indeed this curve was performed using cores from Crete, Dye 3 and Camp Century and the nitrate contents at these locations are very similar (about 1 pEq. $1^{-1}$ Herron (19)) and the HC1 content is probably insignificant (Hamner et a 1. (20)).

\section{POSSIBLE EFEECT OF OTHER MPURITIES}

The E.C.M. results of the 56 ice sections ( $20 \mathrm{~cm}$ long) and taken roughly every 40 meters from the 2083 m Vostok core are reported in Fig. 6, plotted versus their corresponding total acidity. For 47 samples, the acid components were identified, but for the remaining nine, the high level of the total ionic load (up to $30 \mathrm{pEq}$. $1^{-1}$ ) prevents accurate estimation of $\mathrm{HNO}_{3}$ and $\mathrm{HCl}$ contributions. In the 47 samples, $\mathrm{H}_{2} \mathrm{SO}_{4}$ contributions to the total acidity are preponderant (60 to $\left.90 \%\right)$ and the variations are in the range of 0.4 to $4.5 \mu \mathrm{Eq} .1$. HNO 3 and $\mathrm{HCl}$ vary in the range of 0.16 to $0.48 \mathrm{\mu Eq}$. $1^{-1}$ and their contributions are so ${ }^{3}$ small that the calculation of the $\alpha$ and $b$ coefficients of the calibration curve is not significant. However if we adopt the calibration curve we obtained here above, the correlation coefficient is 0.91 for these 47 values.

In Fig. 5, the set of nine values is obviously different with respect to the calibration curve. For a given $\mathrm{H}^{+}$concentration, a reduction of the E.C.M. signal is observed for those samples containing high impurity concentrations (see calcium content reported Fig. 5).

These nine cores are from the glacial age and moreover reveal the highest salt content of our profile $\left(10^{-9} \mathrm{~g} \cdot \mathrm{g}^{-1}\right)$. As developed by Legrand (17) (this volume), during glacial,çonditions, the ice contains large amount of sea salt (mainly NaC1 and some $\mathrm{K}^{+}, \mathrm{Ca}^{++}, \mathrm{Mg}^{++}, \mathrm{SO}_{4}{ }^{1-}$ ) terrestrial salts (mainly CaSO${ }_{4}$ ) and insoluble species (various aluminosilicates, Petit et a1. (21)). Sea salt would not significantly influence the current (Hammer (1)). Furthermore, as demonstrated by Legrand (17), (8), it is important to note that calcium is present in Antarctic ice during the coldest time period in the form of $\mathrm{CaSO}_{4}$. This is not the case for Greenland ice cores in which Hammer (1) pointed out high ${ }^{4}$ calcium contents associated with alcalic ice $(\mathrm{pH}=7)$. The explanation for this phenomenon therefore does not seem to be linked to the soluble species. 


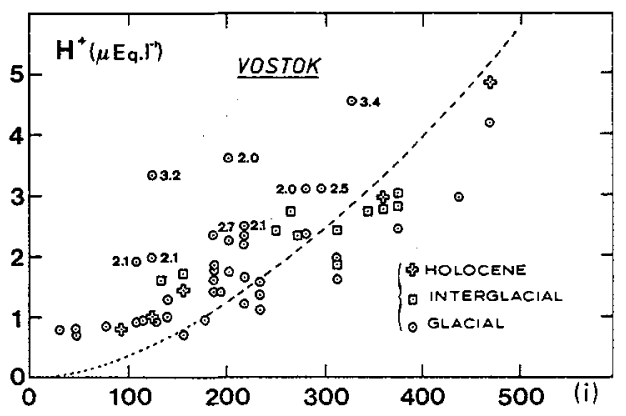

Fig. 5 : Total acidity $\left[\mathrm{H}^{+}\right]$as a function of E.C.M. signal for samples of different climatic periods from the $2083 \mathrm{~m}$ Vostok core. Dots with numbers refer to samples from the glacial age (with calgium concentrations higher than $2 \mu \mathrm{Eq} \cdot 1^{-1}$ as indicated by the number). The broken line is a mean calibration curve calculated from eq. (1) assuming a constant contriqution of $\mathrm{HNO}_{3}+\mathrm{HCl}$ equal to 0.3 $\mu \mathrm{Eq} \cdot 1^{-1}$ would be excepted for value of $\mathrm{H}^{+}$ near zero.

High calcium content is associated with high aluminosilicate content (as suggested by the strong correlation between $\mathrm{Al}$ and $\mathrm{Ca}^{++}$contents obtained by Legrand $\left.(8)\right)$.. Aluminosilicates are insoluble in water (at $\mathrm{pH}=5$, see Legrand ( 8 )) but sodium present in these compounds is easily exchanged with proton at $\mathrm{pH}=2.3$ according to the reversible reaction (Stumm and Morgan (22)) :

Cation-Aluminosilicates $+\mathrm{H}^{+}+\mathrm{H}_{2} \mathrm{O} \leftrightharpoons \mathrm{H}_{4} \mathrm{SiO}_{4}+\mathrm{Na}^{+}+$Aluminosilicates

As previously discussed by Wolff and Paren (2), both $\mathrm{H}_{2} \mathrm{SO}_{4}$ and insoluble particles are probably located in the ice at grain boundaries. In this case, at grain boundaries, the $\mathrm{pH}$ is probably close to one and aluminosilicates can partiy exchange cations with protons. When we melt the ice, the $p H$ decreases and the preceding reaction shifts completely to the left. Therefore, the exchange between acid and aluminosilicates can explain the decrease of the E.C.M. signal when both are present at the grain boundaries.

\section{CONCLUSION}

In addition to the glaciological interest of the detection of a "twin" peak at various Antarctic locations, this study shows that the E.C.M. is well correlated with the $\mathrm{H}^{+}$content of the meltwater (at least at one location). However, HNO and HCl appear to be more effective (by a factor 1.5 to 2.0 ) than $\mathrm{H}_{3} \mathrm{SO}_{4}$ on the DC conductivity of ice. Our results therefore suggest that the $\mathrm{H}_{2} \mathrm{SO}_{4}{ }^{4}$ acts as a monoacid in the ice. This would be compatible with a high concentration at the location of this impurity in ice (possibly at the grain boundary). The effect of insoluble impurities is negligible, but becomes more sensitive at high concentration levels as found in Ice-Age layers. This is not due to the reaction of acid with carbonate, as observed in Greenland, but rather to the reaction with a luminosilicates found in Antarctic ice. The resulting effect is also a weaker correlation between acidity of meltwater and DC conductivity.

Finally, for Antarctic ice, because HCl and HNO contents vary greatly for different geographical locations, the interpretation of E.C.M. profiles in terms of volcanic input requires confirmation by comprehensive chemical studies. Further work (electrical and chemical measurements) may also provide valuable aid in locating impurities within the lattice.

\section{ACKROALEDGERERTS}

This study was supported by CNRS, Programme National d'Etude de la Dynamique du Climat and by Programme Interdisciplinaire de Recherche sur la Préision et la Surveillance des Eruptions Volcaniques. It was supported on the field by Terres Australes et Antarctiques Françaises, Expéditions Polaires Franqaises, NSF (Division of Polar Programs) and the Soviet Antarctic Expeditions. We are grateful to US, Soviet and French participants during field seasons at South Pole and Vostok stations. 


\section{REFERENCES}

(1) C.U. Hammer, J. of Glaciol., 25 (1980) 359-372.

(2) E.W. Wolff and J.G. Paren, J, Geophys. Res., 89 (1984) 9433-9438.

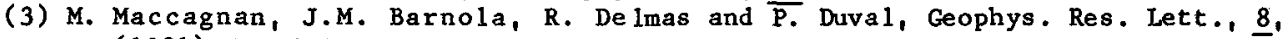
(1981) 970-972.

(4) M. Maccagnan and P. Duval, Ann. Glaciol., 3 (1982) 195-198.

(5) J.A. Schwander. Thesis, Universität Bern (1984) p. 79.

(6) F. Zanolini, Thesis, Universite de Grenoble (1982) p. 85.

(7) M. Legrand and R.J. Delmas, Nature, (submitted).

(8) M. Legrand, Thesis, Universite de Grenoble (1985) p. 439.

(9) F. Zanolini, R.J. Delmas and M. Legrand, Ann. Glaciol. 7 (1985) 70-75.

(10) C. Lorius, J. Jouze 1, C. Ritz, L. Merlivat, N. I. Barkov, Y.S. Korotkevitch and V.M. Kot lyakov, Nature, 316 (1985) 591-596.

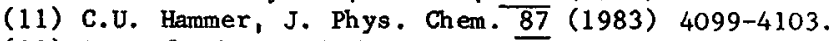

(12) A. Nefte1, M. Andrée,J.A. Schwander and B. Stauffer, Geophys. Mon. 33 (1983) 32-38.

(13) J.M. Reynolds and J.G. Paren, J. Glaciol. 106 (1984) 289-295.

(14) M. Legrand, A.J. Axistarain and R.J. Delmas, Ana1. Chemistry 54 (1982) 1336-1339.

(15) M. Legrand, M. De Angelis and R.J. Delmas, Anal. Chem. Acta $15 \overline{6}(1984) 181-192$.

(16) M. Legrand and R.J. Delmas, Atmos. Environ. 18 (1984) 1867-1874.

(17) M. Legrand, J. of Phys. (this volume).

(18) M. Maccagnan, Thesis, Universite de Grenoble (1981) p.95.

(19) M.H. Herron, J. Geophys. Res. 87 (1982) 3052-3060.

(20) C.U. Hammer, H.B. Clausen, W. Dansgaard, A. Neftel, P. Kristinsdottir and E. Johnston, The Greenland ice sheet Program, An. Geophys. Union, Geophys. Monogr. (1985) 90-94.

(21) J.R. Petit, U. Ezat, N.I. Barkov and V.N. Petrov, Scanning Electron Microscopy (1983) 1627-1633.

(22) W. Stumm and J.J. Morgan, Aquatic Chemistry (Wiley - Interscience), chapter 8 (1970). 